Article

\title{
Mechanisms and Applications of Pressure Relief by Roof Cutting of a Deep-Buried Roadway near Goafs
}

\author{
Peng $\mathrm{Li}^{1,2}$, Xingping Lai ${ }^{1, *}$, Peilin Gong ${ }^{3, *}$, Chao $\mathrm{Su}^{3}$ and Yonglu Suo ${ }^{1}$ \\ 1 Energy School, Xi'an University of Science and Technology, Xi'an 710054, China; \\ 17103077001@stu.xust.edu.cn (P.L.); shiya@xust.edu.cn (Y.S.) \\ 2 Department of Mining Engineering, Shanxi Institute of Energy, Jinzhong 030600, China \\ 3 College of Mining Technology, Taiyuan University of Technology, Taiyuan 030024, China; \\ suchao0110@link.tyut.edu.cn \\ * Correspondence: laixp@xust.edu.cn (X.L.); plgong@126.com (P.G.); Tel.: +86-153-3360-2580 (P.G.)
}

Received: 23 September 2020; Accepted: 30 October 2020; Published: 2 November 2020

\begin{abstract}
Affected by high ground stress, the surrounding rock control of a roadway is one of the most important factors restricting the utilization of deep resources. Therefore, it is necessary to propose a method to improve the stress environment of the deep-buried roadway and reduce its deformation. The article focuses on the 121,302 machine roadway in Kouzidong coal mine to analyze the large deformations of roadways near goafs (RNGs) in deep coal mines and reveal the mechanisms related to pressure relief via roof cutting. Through physical simulation, overburdened structures and the migration laws of RNGs in deep coal mines are studied, and the overburdened RNGs will eventually have a double short-arm " $\mathrm{F}$ "-type suspended roof structure. The superposition movement of the structure is the prime cause for the large deformation of the RNGs considered here. Artificial roof cutting can weaken the superposition effect of the double " $F$ " structure and induce the roof to produce a new fracture. Meanwhile, sliding deformation along the fault line releases greater stress, and the cut roof can better fill the goaf. The stress distribution ratio between goafs and the coal pillar is improved. Here, a mechanical model of key block $\mathrm{B}^{\prime}\left(\mathrm{KBB}^{\prime}\right)$ is considered and the stability criterion of $\mathrm{KBB}^{\prime}$ is obtained. According to the theoretical calculation here, the stress of a coal pillar could be reduced by $19.14 \%$ when $\mathrm{KBB}^{\prime}$ is cut along the edge of the coal pillar in the 121,302 machine roadway. After engineering verification, the field observation result shows that the deformation of the 121,302 machine roadway is reduced by more than $50 \%$ after roof cutting.
\end{abstract}

Keywords: deep coal mine; roadway near goaf; roof cutting and pressure relief; similarity simulation

\section{Introduction}

In the wake of the continual improvement of mining intensity and dimensions in China, many ore districts have gradually turned to deep mining. Being affected by the lateral bearing stress of adjacent goafs and the advanced bearing stress of caving faces, deep coal mine roadways near goafs (RNGs) feature high stress and strong mining potential, resulting in large deformations and long-term, serious damage to roadway surrounding rock, which has become the main problem that prevents effective mining of deep coal resources [1-3].

To settle the problem of surrounding rock control for roadways near goafs in deep mines, experts and scholars have developed many studies on the properties of surrounding rock and various support technologies. Xie et al. studied the physical properties and mining response characteristics of deep-buried coal and rock. The results showed that the tensile strengths of deep-buried coal rocks were small, while the compressive strengths were well above the average compressive strengths of shallow coal rocks, and the axial strain and volume strain were also greater than the shallow coal rocks, 
indicating plasticity [4]. Yuan et al. derived a boundary equation for a plastic zone of surrounding rock in a deep-buried roadway, then deduced an evolution law for the plastic zone morphology [5]. To address the problem of the rheological deformation of roadways, Sun et al. proposed a new and efficient jet grouting technology and studied its control effect on roadway stability [6]. Yang et al. found that after roadway excavation, the surface stress of the roadway first shows a high stress concentration. When the stress on the surface is gradually reduced, the failure area spreads to deep surrounding rock, finally leading to a large stress relaxation area [7]. Wang et al. put forward the notion of "high strength, integrity, and pressure relief"; meanwhile, research of a novel concrete support system was carried out [8]. Shreedharan et al. carried out stability studies on two different roadway shapes in a deep coal mine [9]. Jiang et al. took the deep roadway in Yangcheng coal mine as a case to research the failure mechanism of a deep-buried roadway featuring soft composite rock [10].

For roadways near goafs in deep mines, surrounding rock deformation is still uncontrollable via altering the surrounding rock properties and the addition of support technologies. At this time, ameliorating the stress state of roadway surrounding rock should firstly be carried out using manual pressure relief methods under appropriate conditions [11-14]. Common pressure relief methods at present include roof cutting [15], large-diameter drilling [16-18], and bottom-cutting [19], among which pressure relief via roof cutting is the most commonly used method. Research on roof cutting and pressure relief technology has mainly focused on the problems of preventing retaining roadway deformation or roadways with hard roofs. There are relatively few studies on the application of roof cutting for pressure relief in the context of stability control for RNGs in deep coal mines. Wang et al. introduced a hydraulic fracturing directional roof cutting technology to solve the existing problems of pressure relief by cutting the roof of a retaining roadway [15]. Liu et al. used hydraulic fracturing techniques to cut a hard roof to reduce pressure [20]. Wang et al. introduced the fundamental processes for a roof cutting and pressure relief method without an advanced heading or section pillar [21]. Liu et al. discussed the effects of the location and angle of roof cutting on the stability of surrounding rock in a tunnel, thereby determining an optimal scheme [22].

The 121,302 machine roadway of the Kouzidong coal mine belongs to a typical deep-buried and high-stress roadway located near goafs. Large deformation problems occur when mining the working face, where the main effect is that the coal pillar side expands and bulges outwards, and the whole coal pillar moves into the roadway and protrudes, as shown in Figure 1. This paper comprehensively uses theoretical analysis, physical similarity simulation, and field observation to study the mechanisms of roof cutting by the roof cutting of a deep-buried roadway near goafs. The effectiveness of the unloading of pressure by roof cutting in an RNG in a deep coal mine is verified.

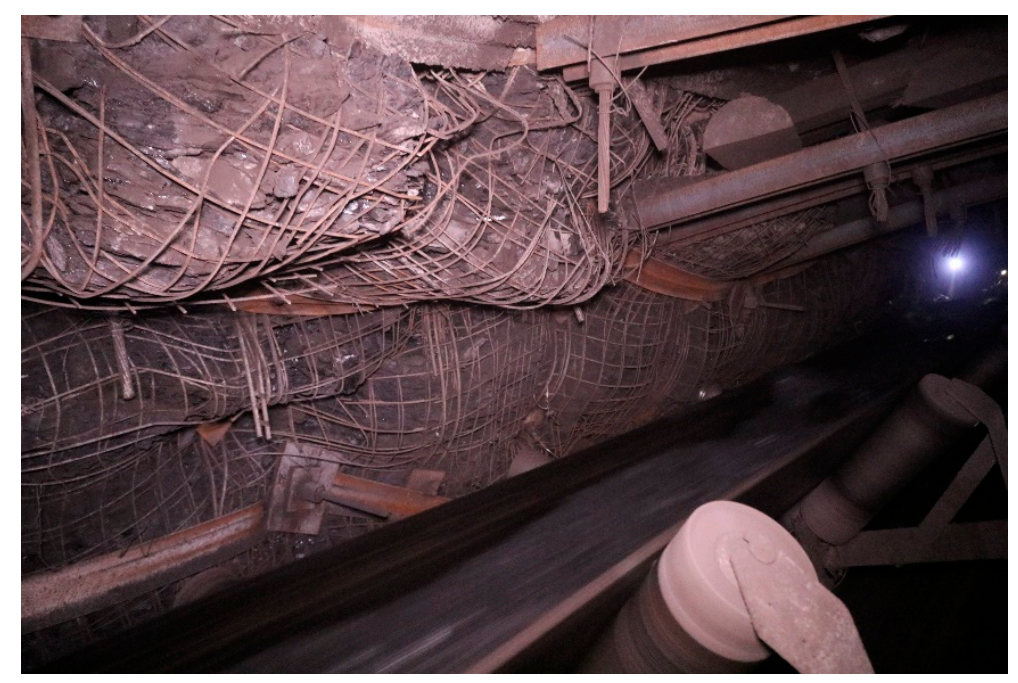

Figure 1. Deformation characteristics of the 121,302 machine roadway. 


\section{Background}

The 121,302 working face is a $-976 \mathrm{~m}$ horizontal caving face of the Kouzidong coal mine, mining the 13-1 coal seam and featuring an open-cut length of $350 \mathrm{~m}$, a coal bed pitch of $6^{\circ}$, a thickness of $4.9 \mathrm{~m}$, and a buried depth that exceeds $1000 \mathrm{~m}$. The machine roadway of the 121,302 working face is a coal conveying roadway. The width of the driving area is $5.8 \mathrm{~m}$, while the height is $4.1 \mathrm{~m}$. The coal pillar width of the adjacent 121,301 caving face is $15 \mathrm{~m}$. The caving face layout and roof strata structure are shown in Figure 2.

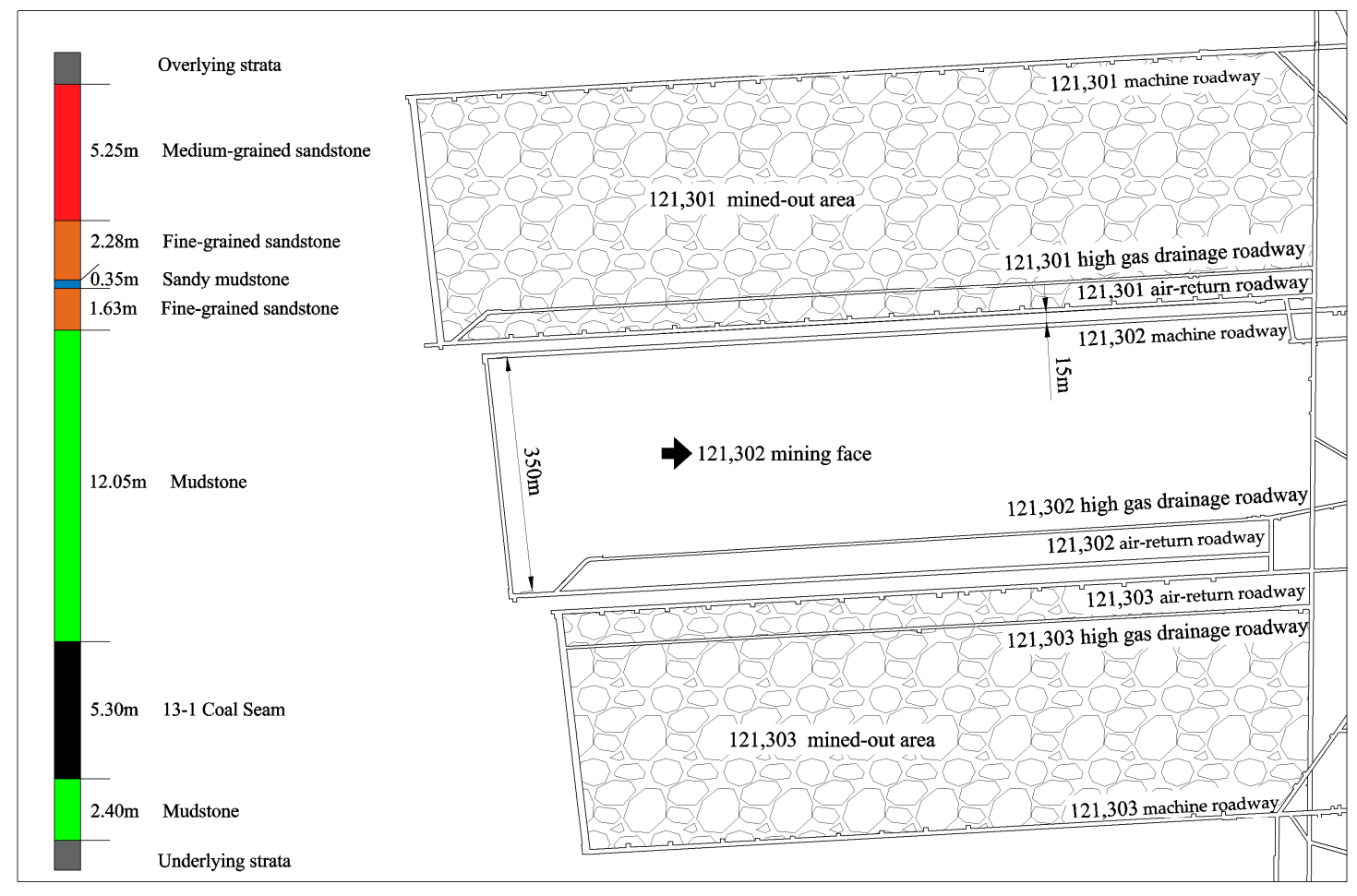

Figure 2. The 121,302 caving face layout and roof strata structure.

\section{Physical Simulation Experiment of Pressure Relief by Roof Cutting in an RNG}

To delve into the mechanism of pressure relief by roof cutting for an RNG, firstly, the overlying rock structure and migration law of the adjacent roadway should be studied to find the source of the high stress in the surrounding rock of the roadway; meanwhile, a physical simulation experiment is an effective method to study the structure and migration law of overburdened rock [23-25]. Therefore, in this paper, based on the mechanical roadway of the 121,302 working face in the Kouzidong coal mine, through physical similarity simulation, the overburdened structure and migration law of the RNG are studied.

\subsection{Physical Simulation Model}

A plane strain flexible loading test device was used for the physical similarity simulation, as shown in Figure 3. The device can accommodate a physical model of $3 \mathrm{~m}$ in length, $0.2 \mathrm{~m}$ in width, and $3 \mathrm{~m}$ in height. This model mainly studies the overburdened structure of a roadway. In order to facilitate observation, the selection of a geometric similarity scale needs to take into account the roadway size and appropriately reduce the length of the working face in the model. After comprehensive consideration, it was determined that the geometric similarity ratio was 100:1 and the bulk density similarity ratio was 1.5:1, hence the stress similarity ratio was 150:1. Table 1 shows the properties of the roof strata of the 121,302 working face. The information for each layer of the physical model is shown in Table 2 . The strata displacement of the model was monitored by a digital image correlation (DIC) instrument 
and the model stress was collected by the CM-2B- 80 strain acquisition instrument. There were three measuring lines that were implanted in the physical model to observe the stress and movement of the physical model. Measuring line A contained 75 micro-soil stress sensors to measure the vertical stress of the model. Measuring lines B and C contained 10 and 2 survey points, respectively, which were used to observe the surface displacement of the roadway.

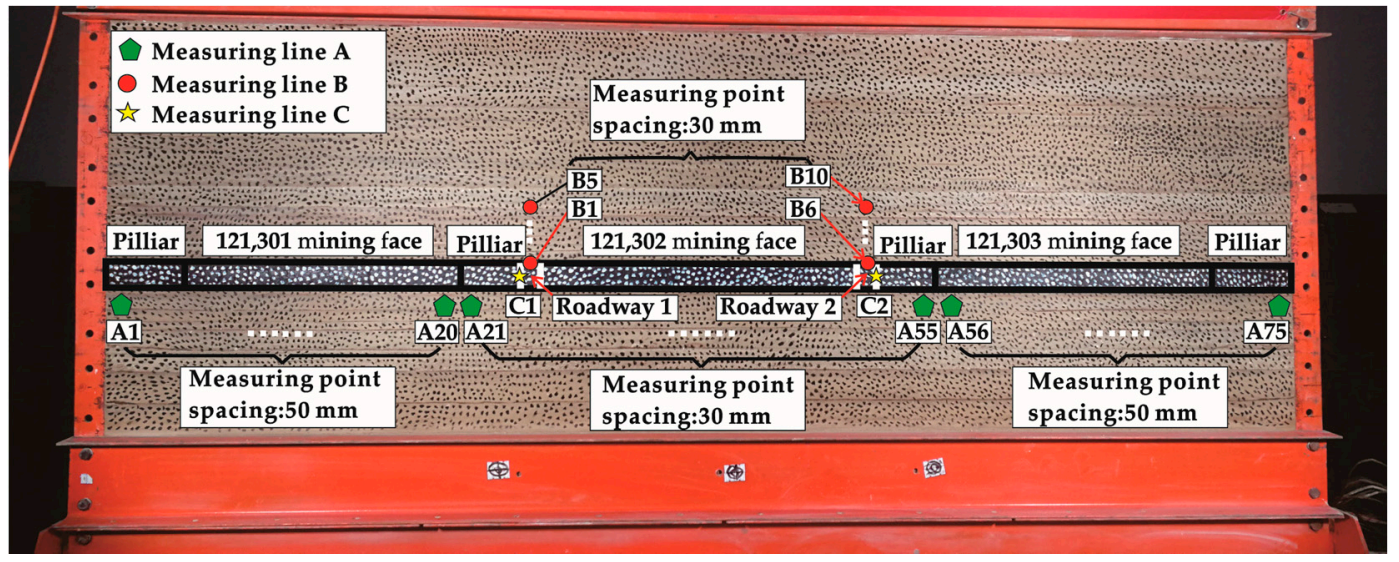

Figure 3. Physical model and measuring line layout.

Table 1. The properties of the roof strata of the 121,302 working face.

\begin{tabular}{ccc}
\hline Rock Character & Density/kg $\mathbf{m}^{-3}$ & Compressive Strength/MPa \\
\hline Medium-grained sandstone (MGS) & 2475 & 42.5 \\
Fine-grained sandstone (FGS) & 2350 & 44.3 \\
Sandy mudstone (SM) & 2300 & 32.5 \\
Mudstone & 2250 & 28.2 \\
Coal & 1450 & 13.5 \\
\hline
\end{tabular}

Table 2. Strata thicknesses and proportions in the physical model.

\begin{tabular}{cccccccc}
\hline Lithology & $\begin{array}{c}\text { Thickness } \\
(\mathbf{c m})\end{array}$ & Proportion & $\begin{array}{c}\text { Weight of } \\
\text { Each } \\
\text { Layer } \mathbf{( k g})\end{array}$ & $\begin{array}{c}\text { Amount } \\
\text { of Sand } \\
\mathbf{( k g )}\end{array}$ & $\begin{array}{c}\text { Amount } \\
\text { of Lime } \\
\mathbf{( k g})\end{array}$ & $\begin{array}{c}\text { Amount of } \\
\text { Gypsum } \\
\mathbf{( k g )}\end{array}$ & $\begin{array}{c}\text { Amount } \\
\text { of Water } \\
\mathbf{( k g )}\end{array}$ \\
\hline Overlying strata & 20 & 773 & 160.0 & 140.0 & 14.0 & 6.0 & 20.0 \\
Mudstone & 15 & 537 & 120.0 & 100.0 & 6.0 & 14.0 & 15.0 \\
MGS & 5 & 337 & 44.0 & 33.0 & 3.3 & 7.7 & 5.5 \\
FGS & 2 & 355 & 16.7 & 12.5 & 2.1 & 2.1 & 2.1 \\
SM & 1 & 455 & 8.2 & 6.5 & 0.8 & 0.8 & 1.0 \\
FGS & 2 & 355 & 16.7 & 12.5 & 2.1 & 2.1 & 2.1 \\
Mudstone & 12 & 537 & 96.0 & 80.0 & 4.8 & 11.2 & 12.0 \\
13-1 coal & 5 & 573 & 25.8 & 21.5 & 3.0 & 1.3 & 3.2 \\
Mudstone & 3 & 537 & 24.0 & 20.0 & 1.2 & 2.8 & 3.0 \\
FGS & 5 & 355 & 41.8 & 31.3 & 5.2 & 5.2 & 5.2 \\
SM & 10 & 455 & 81.8 & 65.4 & 8.2 & 8.2 & 10.2 \\
Underlying strata & 20 & 773 & 160.0 & 140.0 & 14.0 & 6.0 & 20 \\
\hline
\end{tabular}

In this study, we first simulated the 121,301 and 121,303 working faces and set the model to consider $30 \mathrm{~min}$ after mining. The excavation of roadways 1 and 2 was started to form the initial state before the mining of the 121,302 working face. Then, a steel wire rope that was buried in advance was used to cut the roof, and the cutting height was $30 \mathrm{~cm}$. Finally, the 121,302 working face was simulated, and the roof migration rules and deformations of roadways 1 and 2 were compared. Considering that the width of the experimental device was too small to simulate the working face advancing forward, the coal seam of the 121,302 working face was excavated from the middle to both sides during the experiment, and this process was carried out 14 times in total. 


\subsection{Overlying Strata Migration Law of the RNG}

The initial state of the isolated working face before mining is shown in Figure 4a. At this time, the key layer was bent and subsided and the roof fracture line was located above the coal pillar. Along the fault line, the key layers were divided into rock block $A$ and key block B' (KBB'). The overlying rock of the RNG formed a long-arm " $\mathrm{F}$ "-type hanging arch structure.

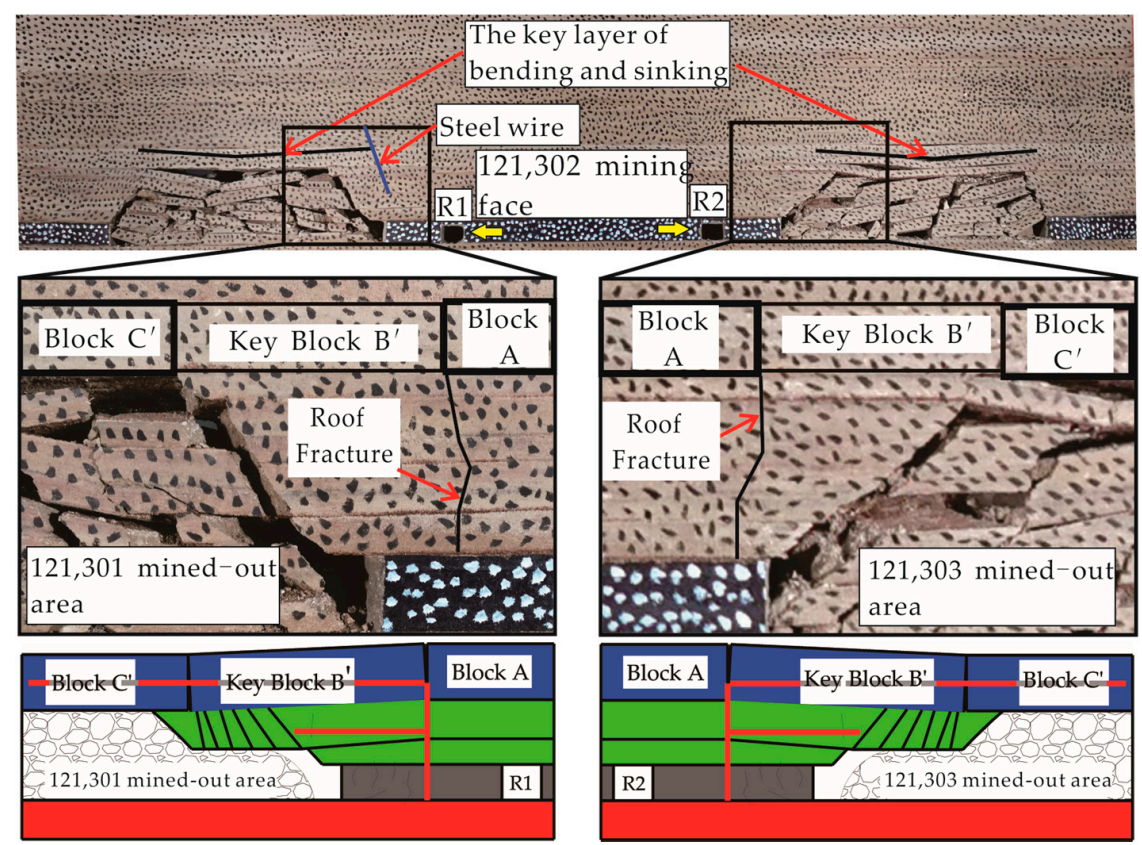

(a)

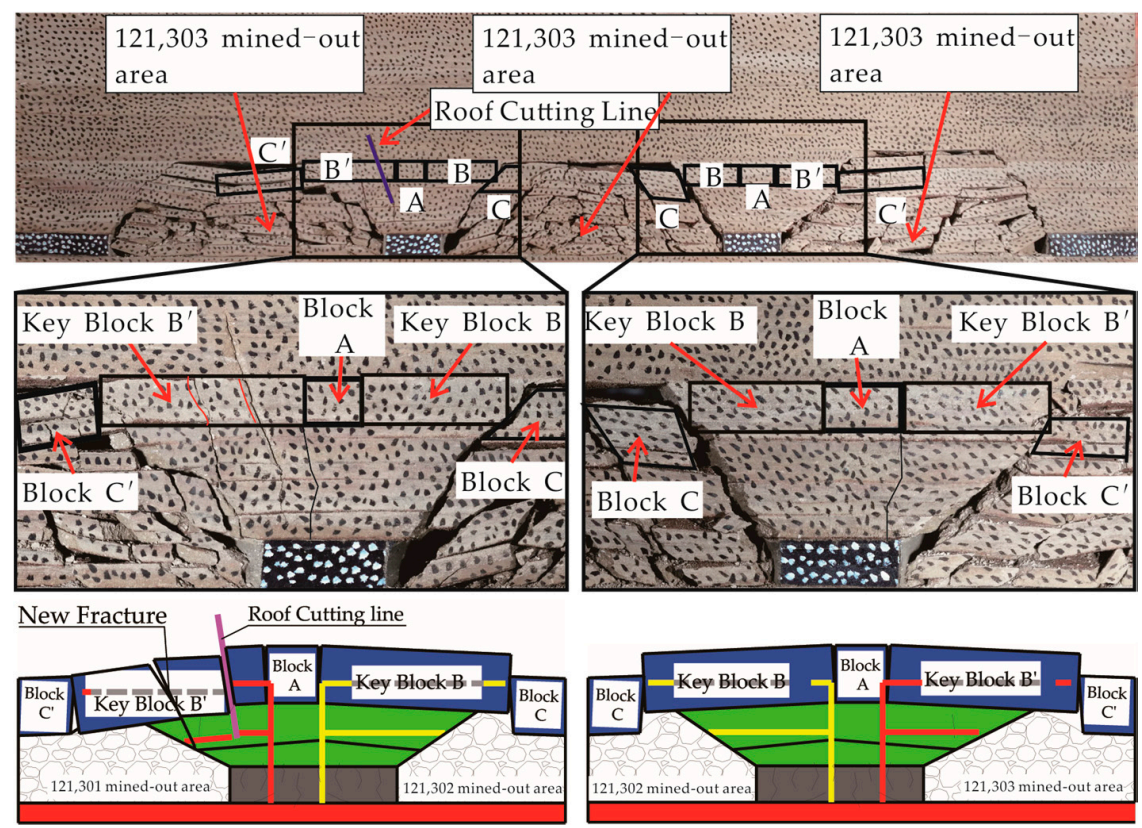

(b)

Figure 4. Layout of the overlying strata migration law for the roadway near goafs (RNG). (a) Long-arm "F"-type hanging roof structure. (b) Double short-arm " $F$ "-type hanging roof structure.

When the mining of the 121,302 caving face was finished, the key layer of the adjacent working face was broken and the long-arm " $\mathrm{F}$ "-type hanging roof structure on the RNG changed to a short-arm "F"-type hanging roof structure, as shown in Figure $4 \mathrm{~b}$. The overlying rock on the solid coal side 
underwent the same structural evolution and formed a double short-arm " $\mathrm{F}$ "-type hanging roof structure above the coal pillar. Compared with the cutting side, the double short-arm " $\mathrm{F}$ "-type suspended roof structure on the non-cutting side moved simultaneously under the action of support pressure, while $\mathrm{KBB}$ ' of the " $\mathrm{F}$ "-type suspended roof structure fell into the goaf along the top cutting line, which reduced the length of the " $\mathrm{F}$ "-type suspended roof structure. A new fracture was formed and a large sliding deformation along the fracture line was produced.

\subsection{Analysis of Monitoring Results of Physical Simulation}

Figure 5 shows the overall vertical stress distribution of the model before and after the mining of the 121,302 caving face. The comparison shows that the stress reduction area was formed after the mining of the 121,302 caving face, and that the stress was shifted to the coal pillars on both sides. In terms of the peak stress, the initial stress peak of the roof-uncut side was $0.33 \mathrm{MPa}$, the stress superposition of the 121,302 working face after mining was $0.39 \mathrm{MPa}$, the initial stress peak of the roof-cut side was $0.35 \mathrm{MPa}$, and the peak stress of the 121,302 working face after mining was $0.30 \mathrm{MPa}$. From the point of view of the peak stress position, the stress peaks on both sides were shifted to the goaf side, but the peak stress on the roof-cut side was located at the edge of the goaf, which forced the coal pillar to be lower than in the initial state, while the peak stress position on the uncut side remained situated on the headpiece of the coal pillar. The state of stress of the coal pillar remained high throughout, indicating that after the 121,302 caving face was mined, the supporting pressure of this working face and the adjacent goaf was superimposed and exerted high stress on the coal pillar, and manual roof cutting can shift the peak stress to the goaf in order to improve the stress state of the coal pillar.

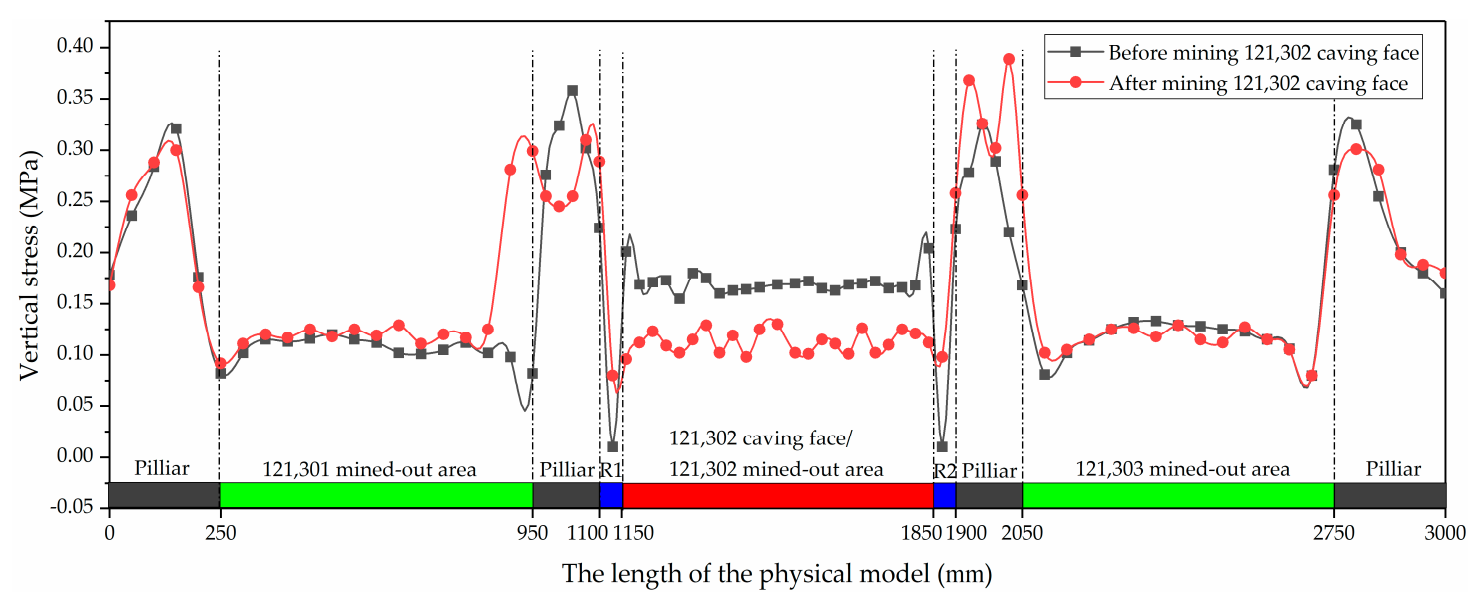

Figure 5. Vertical stress curve of measuring line A before and after mining of the 121,302 caving.

Figure 6 shows the variation of the RNG roof and coal pillar displacement in the middle with the advancement of the 121,302 caving face. The displacement curve trends of each vertical displacement measuring point for the roadway roof were roughly the same. After the eighth advance, the key layer was broken, which had a great impact on the roadway roof, and the displacement changed suddenly. After that, with the mining of the caving face, the displacement continued to increase in a small range; the maximum vertical displacement of the roadway at the roof-cut side was $11.24 \mathrm{~mm}$, and the uncut side maximum vertical displacement of the roadway was $15.67 \mathrm{~mm}$. The results show that roof cutting could reduce the vertical displacement of the roadway. The horizontal displacement of the coal pillar sill on the roof-cut side of the roadway changed smoothly, with a maximum displacement of $0.38 \mathrm{~mm}$. The horizontal displacement of the side without roof cutting suddenly changed after the eighth advance of the 121,302 working face. After that, the displacement still increased greatly as the working face advanced, and the maximum horizontal displacement was $2.75 \mathrm{~mm}$, indicating that roof cutting could reduce the horizontal displacement of the coal pillar side of the roadway. 

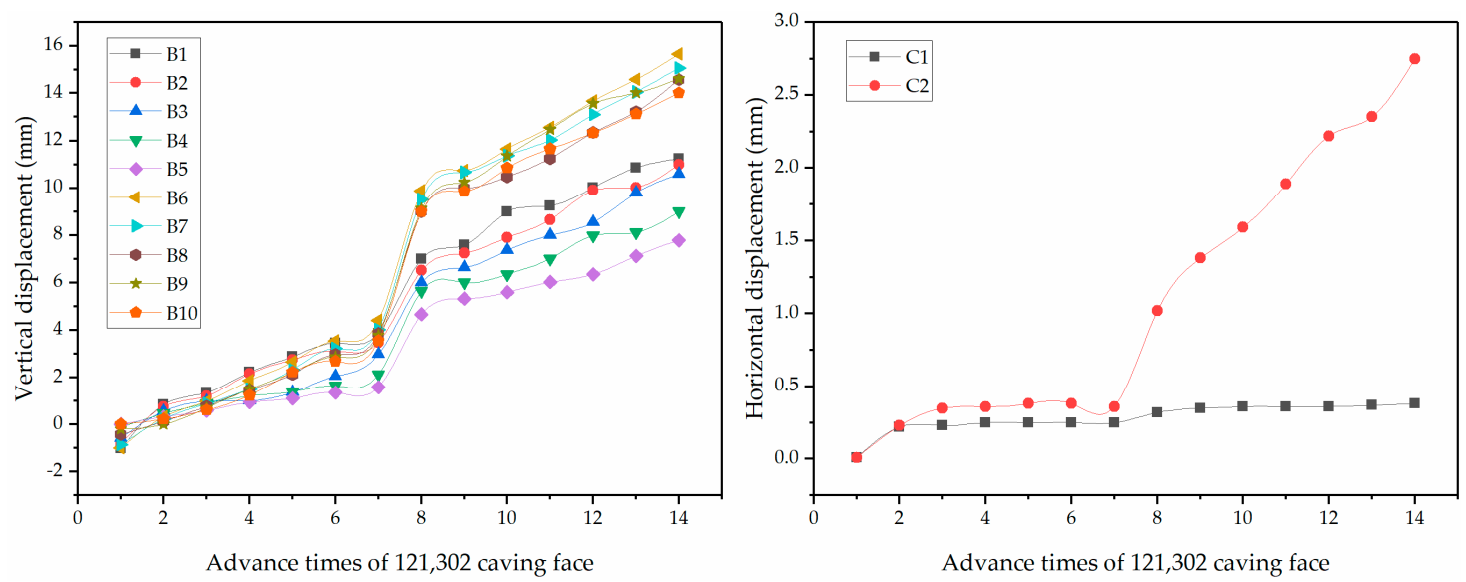

Figure 6. Vertical and horizontal displacement curves of measuring lines B and C.

\section{Theoretical Analysis of Pressure Relief by Roof Cutting in the RNG}

Although the physical similarity simulation experiments have shown that roof cutting can relieve pressure, determining how to quantitatively analyze the influence of roof cutting on the stress state of coal pillars needs further theoretical research. Therefore, this paper established the mechanical model of $\mathrm{KBB}^{\prime}$ and analyzed its stress.

\subsection{Mechanical Model of KBB'}

The mechanical model of KBB' on the RNG was established as shown in Figure 7.

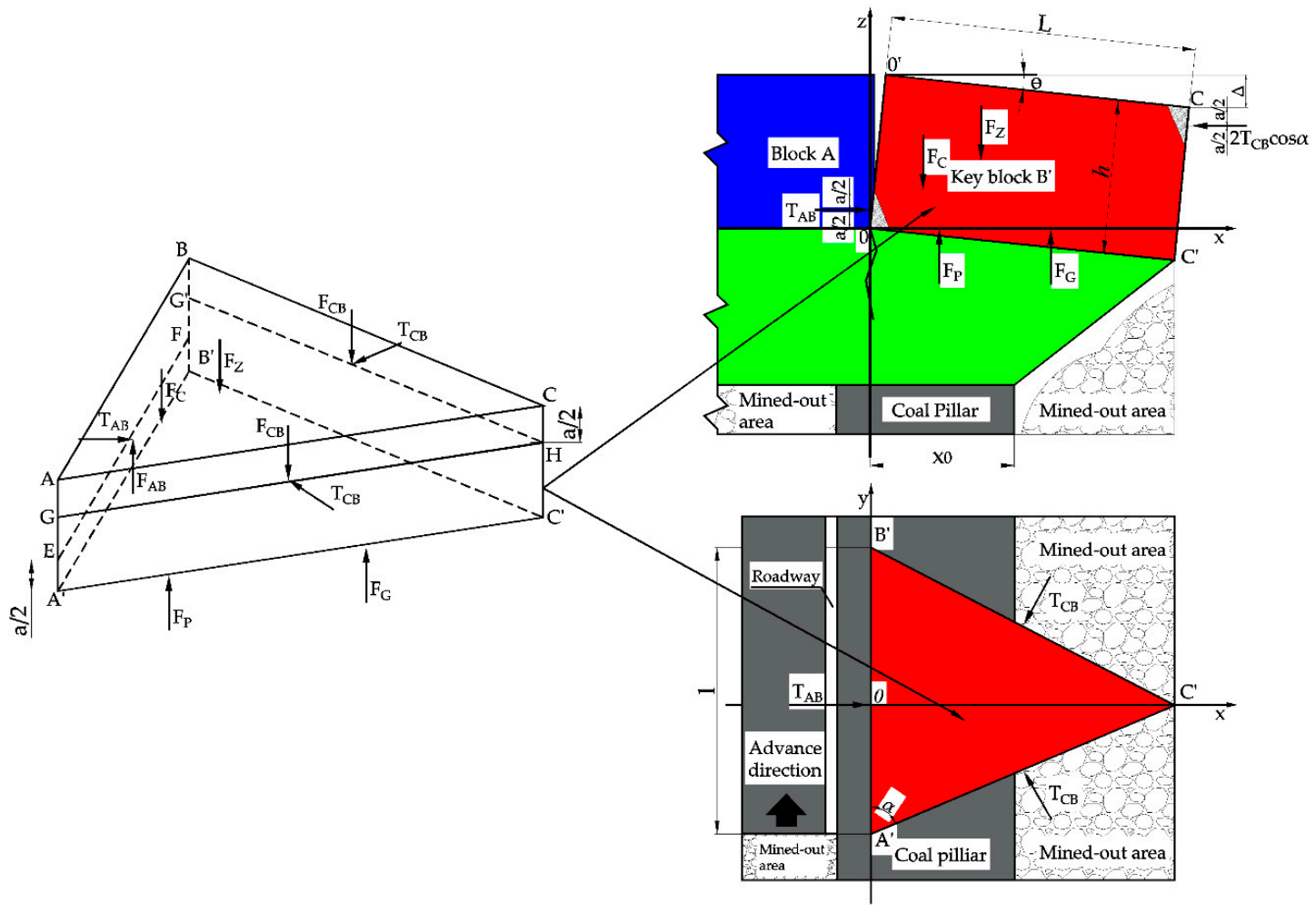

Figure 7. The key block B' mechanical model.

To facilitate the analysis, the force on $\mathrm{KBB}^{\prime}$ was simplified as follows [26,27]:

(1) At the front and rear, rock block $C$ exerts equal forces on $\mathrm{KBB}^{\prime} . \mathrm{F}_{\mathrm{CB}}$ is the vertical shear of block $\mathrm{C}$ to $\mathrm{KBB}^{\prime}$ and $\mathrm{T}_{\mathrm{CB}}$ is the horizontal thrust of block $\mathrm{C}$ to $\mathrm{KBB}^{\prime}$. The acting point is located at the 
midpoint of GH and G'H, and the height direction $\mathrm{CH}$ is a/2. Additionally, "a" is the length of occlusal contact between blocks;

(2) The vertical shear force and horizontal thrust of rock block $A$ to $K B B$ are denoted as $F_{A B}$ and $T_{A B}$, respectively, which act on the midpoint of $\mathrm{EF}$, and the height is at a/2, EF is the shaft of $\mathrm{KBB}^{\prime}$;

(3) $F_{c}$ is the mining pressure caused by the mining face, $F_{P}$ is the supporting force of the coal pillar, $\mathrm{F}_{\mathrm{G}}$ is the supporting force of the gangue in the goaf, and $\mathrm{F}_{\mathrm{Z}}$ is the self-coincidence force of $\mathrm{KBB}^{\prime}$ and the upper weak rock formation;

(4) $\angle \mathrm{CAB}=\angle \mathrm{ABC}=\alpha$, where $\theta$ is the turning angle of $\mathrm{KBB}^{\prime}$;

(5) $\mathrm{x}_{0}$ is the break position of $\mathrm{KBB}$ :

$$
\mathrm{x}_{0}=\frac{\lambda \mathrm{M}}{2 \tan \varphi_{0}} \ln \left(\frac{\mathrm{k} \gamma \mathrm{H}+\frac{\mathrm{c}_{0}}{\tan \varphi_{0}}}{\frac{\mathrm{c}_{0}}{\tan \varphi_{0}}+\frac{\mathrm{p}_{\mathrm{x}}}{\lambda}}\right)
$$

where $\lambda$ is the lateral pressure coefficient; $c_{0}$ is the cohesion of the coal seam (MPa); $\mathrm{M}$ is the thickness of the coal seam $(\mathrm{m}) ; \varphi_{0}$ is the internal friction angle $\left(^{\circ}\right) ; \mathrm{H}$ is the buried depth of the working face $(\mathrm{m}) ; \gamma$ is the overlying strata bulk density $\left(\mathrm{kN} / \mathrm{m}^{3}\right) ; \mathrm{p}_{\mathrm{x}}$ is the support resistance of the roadside; and $\mathrm{k}$ is the stress concentration coefficient;

(6) 1 is the length of $\mathrm{KBB}^{\prime}$ when following the forward face direction; $\mathrm{L}$ is the fracture size of $\mathrm{KBB}^{\prime}$ when following the inclined direction of the caving face; and $\mathrm{L}$ is when the key layer period collapses, as calculated by Formula (2):

$$
L=1\left(-\frac{1}{S}+\sqrt{\frac{1^{2}}{S^{2}}+\frac{3}{2}}\right)
$$

where $S$ is the caving face length $(\mathrm{m})$.

\subsection{Force Analysis of Key Block B' on Side Roof of Mined-Out Area of the RNG}

1. Mining pressure $\mathrm{F}_{\mathrm{C}}$ is caused by the mining face:

$$
\mathrm{F}_{\mathrm{c}}=\int_{0}^{\mathrm{x}_{0}} \mathrm{f}_{\mathrm{c}}\left[\frac{-2}{\tan \alpha}(\mathrm{x}-\mathrm{L})\right] \mathrm{dx}
$$

In Formula (3), $\mathrm{f}_{\mathrm{c}}$ is the mining stress caused by mining (MPa):

$$
\mathrm{f}_{\mathrm{c}}=\frac{\mathrm{x}_{0}-\mathrm{x}}{\mathrm{x}_{0}} \mathrm{~K}_{\mathrm{d}} \gamma \mathrm{H}
$$

where $\mathrm{K}_{\mathrm{d}}$ is the superimposed support stress concentration factor, generally taken as between 2 and 5 .

2. Supporting force of the coal and rock masses in the lower part of key block B':

(1) Supporting force $F_{p}$ of the coal pillar:

$$
\mathrm{F}_{\mathrm{p}}=\int_{0}^{\mathrm{x}_{0}} \mathrm{f}_{\mathrm{p}}\left[\frac{-2}{\tan \alpha}(\mathrm{x}-\mathrm{L})\right] \mathrm{dx}
$$

where $f_{p}$ is the strength of the coal pillar (MPa). Owing to the effect of high crustal stress in deep mines, the coal pillar under $\mathrm{KBB}^{\prime}$ is generally at the stage of residual strength after a peak, and, at this time, the coal pillar strength is

$$
\mathrm{f}_{\mathrm{p}}=\frac{1+\sin \xi}{1-\sin \xi} \mathrm{P}_{\mathrm{x}}+\mathrm{R}_{\mathrm{c}}^{\prime}
$$


where $\xi$ is the coal post-peak friction angle $\left({ }^{\circ}\right)$ and $\mathrm{R}_{\mathrm{C}}{ }_{\mathrm{C}}$ is the coal post-peak residual strength (MPa).

(2) Supporting force $\mathrm{F}_{\mathrm{G}}$ of gangue in a goaf:

$$
\mathrm{F}_{\mathrm{G}}=\int_{\mathrm{x}_{0}}^{\mathrm{L} \cos \theta} \mathrm{f}_{\mathrm{g}}\left[\frac{-2}{\tan \alpha}(\mathrm{x}-\mathrm{L})\right] \mathrm{dx}
$$

where $\mathrm{f}_{\mathrm{g}}$ is the supporting force produced by gangue in a goaf (MPa).

$$
\mathrm{f}_{\mathrm{g}}=\mathrm{Kg}\left\langle\mathrm{S}_{0}+\mathrm{x} \sin \theta-\left\{\mathrm{M}-\left[\mathrm{M}(1-\eta) \mathrm{K}_{\mathrm{M}}+\sum \mathrm{h}\left(\mathrm{K}_{\mathrm{Z}}-1\right)\right]\right\}\right\rangle
$$

where $\mathrm{Kg}$ is the support coefficient of the caving gangue $(\mathrm{MPa} / \mathrm{m}) ; \mathrm{S}_{0}$ is the overall subsidence of $\mathrm{KBB}^{\prime}(\mathrm{m}) ; \eta$ is recovery rate of the caving face; $\mathrm{K}_{\mathrm{M}}$ is the crushing expansion coefficient of coal; and $\mathrm{K}_{\mathrm{Z}}$ is the crushing expansion coefficient of caving gangue.

3. Horizontal thrust of block $A$ and $C^{\prime}$ to $K B B^{\prime}$ : According to Figure 6, let $\sum \mathrm{M}_{\mathrm{O}^{\prime}}=0$, then

$$
2 \mathrm{~T}_{\mathrm{CB}} \cos \alpha\left(\mathrm{h}-\frac{\mathrm{a}}{2}\right)+\mathrm{R}_{\mathrm{fp}}+\mathrm{R}_{\mathrm{fg}}=\mathrm{T}_{\mathrm{AB}}\left(\Delta+\frac{\mathrm{a}}{2}\right)+\mathrm{F}_{\mathrm{z}} \frac{\mathrm{L}}{3}+\mathrm{R}_{\mathrm{fc}}
$$

where $\mathrm{R}_{\mathrm{fc}}, \mathrm{R}_{\mathrm{fp}}$, and $\mathrm{R}_{\mathrm{fc}}$ are moments of $\mathrm{F}_{\mathrm{C}}, \mathrm{F}_{\mathrm{P}}$, and $\mathrm{F}_{\mathrm{G}}$ to $\mathrm{EF}$, respectively:

$$
\begin{aligned}
& \mathrm{R}_{\mathrm{fc}}=\int_{0}^{\mathrm{x}_{0}} \mathrm{f}_{\mathrm{c}}\left[\frac{-2}{\tan \alpha}(\mathrm{x}-\mathrm{L})\right] \mathrm{xdx} \\
& \mathrm{R}_{\mathrm{fp}}=\int_{0}^{\mathrm{x}_{0}} \mathrm{f}_{\mathrm{p}}\left[\frac{-2}{\tan \alpha}(\mathrm{x}-\mathrm{L})\right] \mathrm{xdx} \\
& \mathrm{R}_{\mathrm{fg}}=\int_{\mathrm{x}_{0}}^{\mathrm{L} \cos \theta} \mathrm{f}_{\mathrm{g}}\left[\frac{-2}{\tan \alpha}(\mathrm{x}-\mathrm{L})\right] \mathrm{xdx}
\end{aligned}
$$

In Formula (9), a is the length of occlusal contact between blocks $A, C^{\prime}$, and $\mathrm{KBB}^{\prime}$, and $\mathrm{a}=1 / 2(\mathrm{~h}-\sin \theta \cdot \mathrm{L} / 2) ; \Delta$ is the pivotal subsidence of $\mathrm{KBB}^{\prime}$, where $\Delta=\mathrm{L} \sin \theta$; Fz is the $\mathrm{KBB}^{\prime}$ self-weight and its load, where $\mathrm{Fz}=0.5 \mathrm{lL} \gamma_{\mathrm{z}} \mathrm{h}_{\mathrm{z}}$; and the horizontal thrusts of blocks $\mathrm{A}$ and $\mathrm{C}^{\prime}$ to $\mathrm{KBB}^{\prime}$ are the following:

$$
\begin{gathered}
\mathrm{T}_{\mathrm{AB}}=\frac{4 \mathrm{~F}_{\mathrm{z}} \mathrm{L}+12\left(\mathrm{R}_{\mathrm{fc}}-\mathrm{R}_{\mathrm{fp}}-\mathrm{R}_{\mathrm{fg}}\right)}{3(2 \mathrm{~h}-\mathrm{Lsin} \theta)} \\
\mathrm{TC}^{\prime} \mathrm{B}=\frac{2 \mathrm{~F}_{\mathrm{z}} \mathrm{L}+6\left(\mathrm{R}_{\mathrm{fc}}-\mathrm{R}_{\mathrm{fp}}-\mathrm{R}_{\mathrm{fg}}\right)}{3 \cos \alpha(2 \mathrm{~h}-\mathrm{Lsin} \theta)}
\end{gathered}
$$

4. Vertical forces of blocks $A$ and $C^{\prime}$ to $\mathrm{KBB}^{\prime}$ : Considering Figure 6, let $\sum \mathrm{M}_{\mathrm{EF}}=0$, then

$$
2 \mathrm{~F}_{\mathrm{CB}} \frac{\mathrm{L} \cos \theta}{2}+\mathrm{F}_{\mathrm{z}} \frac{\mathrm{L} \cos \theta}{3}+\mathrm{R}_{\mathrm{fC}}=\mathrm{R}_{\mathrm{fp}}+\mathrm{R}_{\mathrm{fg}}+2 \mathrm{~T}_{\mathrm{CB}} \cos \alpha\left(\mathrm{h}-\mathrm{a}-\frac{\mathrm{L}}{2} \sin \theta\right)
$$

The resultant force in the vertical direction is 0 , namely

$$
\mathrm{F}_{\mathrm{AB}}+\mathrm{F}_{\mathrm{P}}+\mathrm{F}_{\mathrm{G}}=2 \mathrm{~F}_{\mathrm{CB}}+\mathrm{F}_{\mathrm{z}}+\mathrm{F}_{\mathrm{C}}
$$

The vertical forces of blocks $\mathrm{A}$ and $\mathrm{C}^{\prime}$ to $\mathrm{KBB}^{\prime}$ are the following:

$$
\begin{gathered}
\mathrm{F}_{\mathrm{CB}}=\frac{2 \mathrm{aT} \mathrm{T}_{\mathrm{CB}} \cos \alpha-\mathrm{R}_{\mathrm{fc}}+\mathrm{R}_{\mathrm{fp}}+\mathrm{R}_{\mathrm{fg}}}{\mathrm{Lcos}}-\frac{\mathrm{F}_{\mathrm{z}}}{3} \\
\mathrm{~F}_{\mathrm{AB}}=2 \mathrm{~F}_{\mathrm{CB}}+\mathrm{F}_{\mathrm{z}}+\mathrm{F}_{\mathrm{C}}-\mathrm{F}_{\mathrm{p}}-\mathrm{F}_{\mathrm{G}}
\end{gathered}
$$

\subsection{Research on the Effect of Roof Cutting on the Stability of $\mathrm{KBB}^{\prime}$ and the Force of the Coal Pillar}

On the basis of "S-R" stability theory [22], there are mainly two ways to consider the instability of $\mathrm{KBB}^{\prime}$. One is where the vertical shear force between $\mathrm{KBB}^{\prime}$ and rock block $\mathrm{A}$ is bigger than the friction force generated by the horizontal thrust between them. The other is that the rotation angle of $\mathrm{KBB}^{\prime}$ is 
too large, which makes the compressive stress caused by the horizontal thrust of rock block A bigger than the compressive strength of the contact surface.

Let $\mathrm{K}_{1}$ be the sliding instability coefficient. To stop $\mathrm{KBB}^{\prime}$ from becoming unstable, the condition $\mathrm{T}_{\mathrm{AB}} \tan \varphi \geq \mathrm{F}_{\mathrm{AB}}$ must be met, thus

$$
\mathrm{K}_{1}=\frac{\mathrm{F}_{\mathrm{AB}}}{\mathrm{T}_{\mathrm{AB}} \tan \varphi}=\frac{3(2 \mathrm{~h}-\mathrm{L} \sin \theta) \mathrm{F}_{\mathrm{AB}}}{\left[4 \mathrm{~F}_{\mathrm{z}} \mathrm{L}+12\left(\mathrm{R}_{\mathrm{fc}}-\mathrm{R}_{\mathrm{fp}}-\mathrm{R}_{\mathrm{fg}}\right)\right] \tan \varphi}
$$

where $\tan \varphi$ is the friction factor between rocks.

Let $K_{2}$ be the squeeze deformation instability coefficient. In order to prevent $\mathrm{KBB}^{\prime}$ from experiencing unstable squeezing deformation, the condition $\mathrm{T}_{\mathrm{AB}}<\mathrm{la} \psi \sigma \mathrm{c}$ must be met, thus

$$
K_{2}=\frac{T_{A B}}{l a \psi \sigma_{c}}=\frac{4 F_{z} L+12\left(R_{f c}-R_{f p}-R_{f g}\right)}{3 l a \psi(2 h-L \sin \theta) \sigma_{c}}
$$

where $\psi$ is the contact coefficient between rock blocks at the corner and $\sigma \mathrm{c}$ is the compressive strength of the rock blocks (MPa).

Let $\mathrm{F}_{\mathrm{m}}$ be the force on the coal pillar. Assuming that the rock under the key layer is in an elastic state and neglecting its own weight, the force on the coal pillar when KBB' becomes unstable is the following:

$$
\mathrm{F}_{\mathrm{m}}=\mathrm{F}_{\mathrm{AB}}-\mathrm{T}_{\mathrm{AB}} \tan \varphi+\mathrm{F}_{\mathrm{z}}+\mathrm{F}_{\mathrm{c}}-\mathrm{F}_{\mathrm{G}}
$$

Considering an engineering background, take $\mathrm{h}=5.25 \mathrm{~m} ; \sum \mathrm{h}=16.31 \mathrm{~m} ; \lambda=1.1 ; \mathrm{k}=3 ; \mathrm{M}=5.3 \mathrm{~m}$; $\mathrm{H}=1000 \mathrm{~m} ; \mathrm{c}_{0}=4.57 \mathrm{MPa} ; \varphi_{0}=35.21^{\circ} ; \gamma=25 \mathrm{kN} / \mathrm{m}^{3} ; \mathrm{P}_{\mathrm{x}}=0.5 \mathrm{MPa} ; \mathrm{S}=342 \mathrm{~m} ; 1=15 \mathrm{~m} ; \xi=25^{\circ} ;$ $\mathrm{R}_{\mathrm{c}^{\prime}}=1.2 \mathrm{MPa} ; \mathrm{K}_{\mathrm{g}}=2.5 \mathrm{MPa} / \mathrm{m} ; \mathrm{s} 0=0.5 \mathrm{~m} ; \eta=0.9 ; \mathrm{K}_{\mathrm{M}}=1.3 ; \mathrm{K}_{\mathrm{z}}=1.2 ; \gamma_{\mathrm{z}}=25 \mathrm{kN} / \mathrm{m}^{3} ; \mathrm{h}_{\mathrm{z}}=10 \mathrm{~m} ; \theta=5^{\circ} ;$ $\tan \varphi=0.35 ; \psi=0.3$; and $\sigma_{\mathrm{c}}=35 \mathrm{MPa}$ to obtain $\mathrm{x}_{0}=10.2 \mathrm{~m} ; \mathrm{L}=17.72 \mathrm{~m} ; \mathrm{K}_{1}=1.17$; and $\mathrm{K}_{2}=0.27$.

Let Lc be the length of $\mathrm{KBB}^{\prime}$ that cuts into the roof of the goaf. For the sake of ensuring the top-cutting effect and reducing the overhanging effect, the reasonable range of $\mathrm{LC}$ is

$$
0 \leq \mathrm{Lc} \leq \mathrm{L}-\mathrm{x}_{0}
$$

Considering an engineering background, the reasonable range of $\mathrm{Lc}$ is $0 \leq \mathrm{Lc} \leq 7.52$. At this time, the functional curves of $\mathrm{K}_{1}, \mathrm{~K}_{2}$, and $\mathrm{F}_{\mathrm{M}}$, with respect to $\mathrm{Lc}$, are shown in Figure 7 .

It can be seen from Figure 8 that $\mathrm{KBB}^{\prime}$ will inevitably fall and lose stability when mining the 121,302 caving face of the Kouzidong coal mine, and it is more prone to slippage and losing stability as the cutting length of $\mathrm{KBB}^{\prime}$ increases. With the increase in the cutting length of $\mathrm{KBB}^{\prime}$, the force of the coal pillar decreases, following a quadratic relationship. The larger the roof cutting length is, the more obvious the pressure relief effect is. When cutting $\mathrm{KBB}^{\prime}$ along the coal pillar, the force of the coal pillar decreases by $19.14 \%$. 


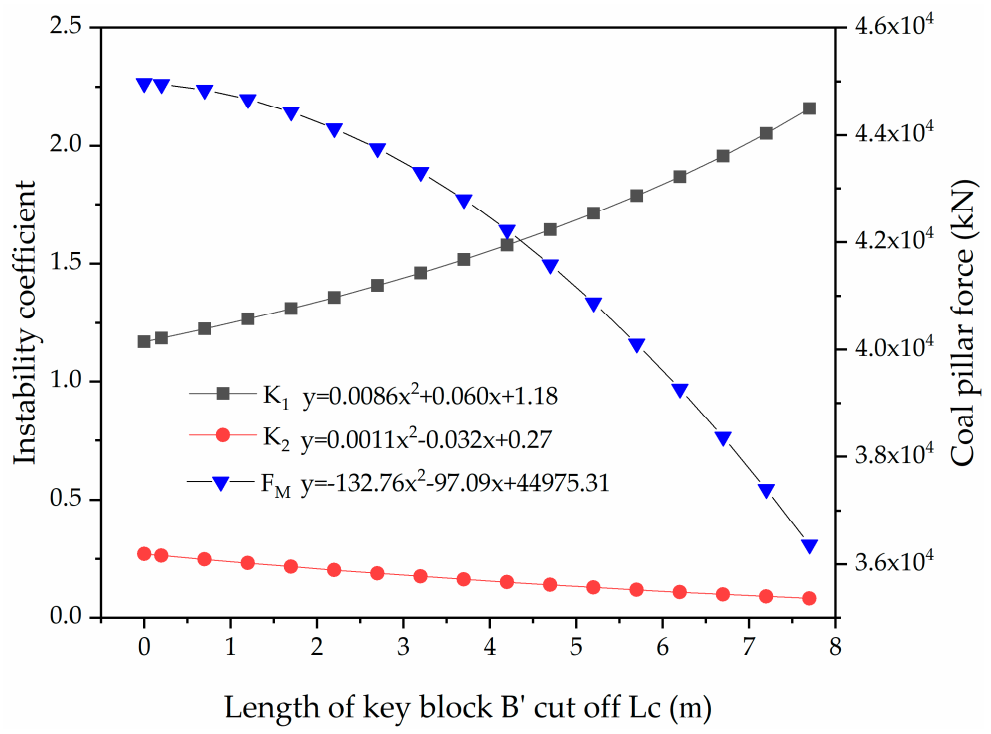

Figure 8. The functional curves of $\mathrm{K}_{1}, \mathrm{~K}_{2}$, and $\mathrm{F}_{\mathrm{M}}$ with respect to Lc.

\section{Engineering Verification}

The hydraulic fracturing roof cutting and pressure relief test was implemented in the 121,302 caving face of the Kouzidong coal mine. Considering the occurrences and changes of strata, the vertical height of the drilling hole was $47.4 \mathrm{~m}$, the drilling spacing was $10 \mathrm{~m}$, the axial angle between the borehole and the tunnel was $10^{\circ}$, and the dip angle was $45^{\circ}$. The pressure relief scheme and station layout are shown in Figure 9. The experiment featured roadway surface displacement measuring points and coal pillar drilling stress measuring points. When considering crushing deep coal on the pillar side, borehole collapse is likely to occur, and the depth of the borehole stress gauge was determined to be 3 and $6 \mathrm{~m}$.

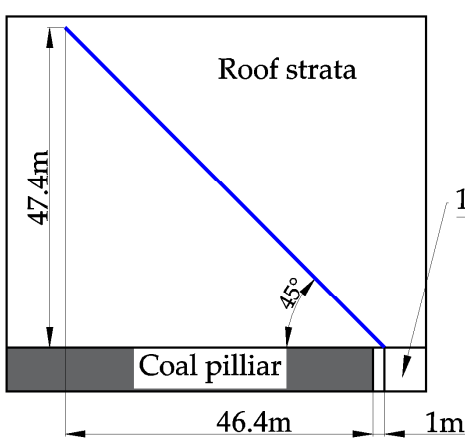

A-A section

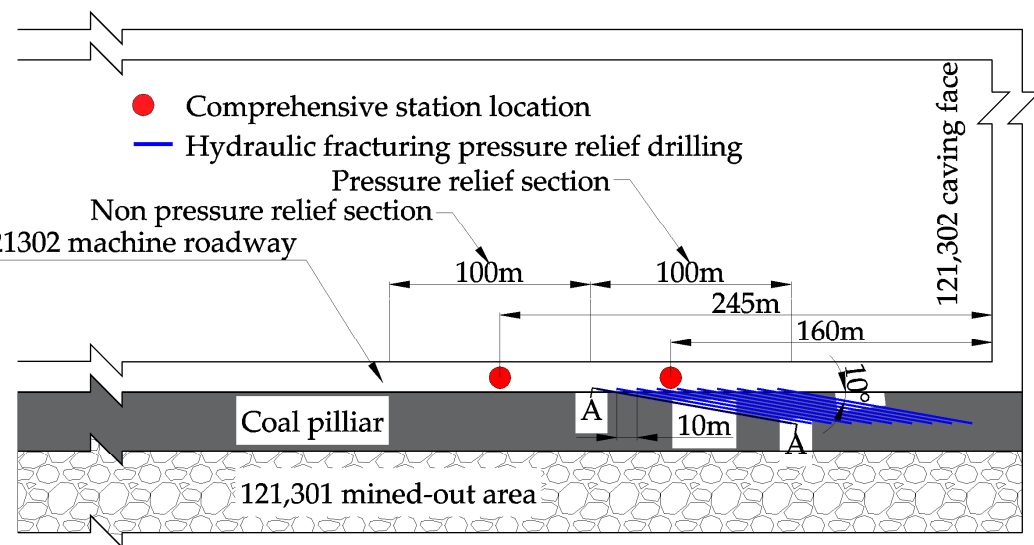

Figure 9. The pressure relief scheme and station layout.

The field observation results are shown in Figure 10. During the mining period, the roadway was affected by strong mining. The cumulative approach of the roof and floor of the non-pressure relief section was $4379 \mathrm{~mm}$, the accumulated deformation of the two sides reached $3529 \mathrm{~mm}$, the cumulative approach of the roof and floor of the pressure relief section was $1915 \mathrm{~mm}$, and the accumulated deformation of the two sides reached $962 \mathrm{~mm}$. In summary, although the roadway featured obvious deformation after the roof was cut and relieved, the deformation of the roadway was reduced by more than $50 \%$ when compared with the roadway situation without pressure relief. 

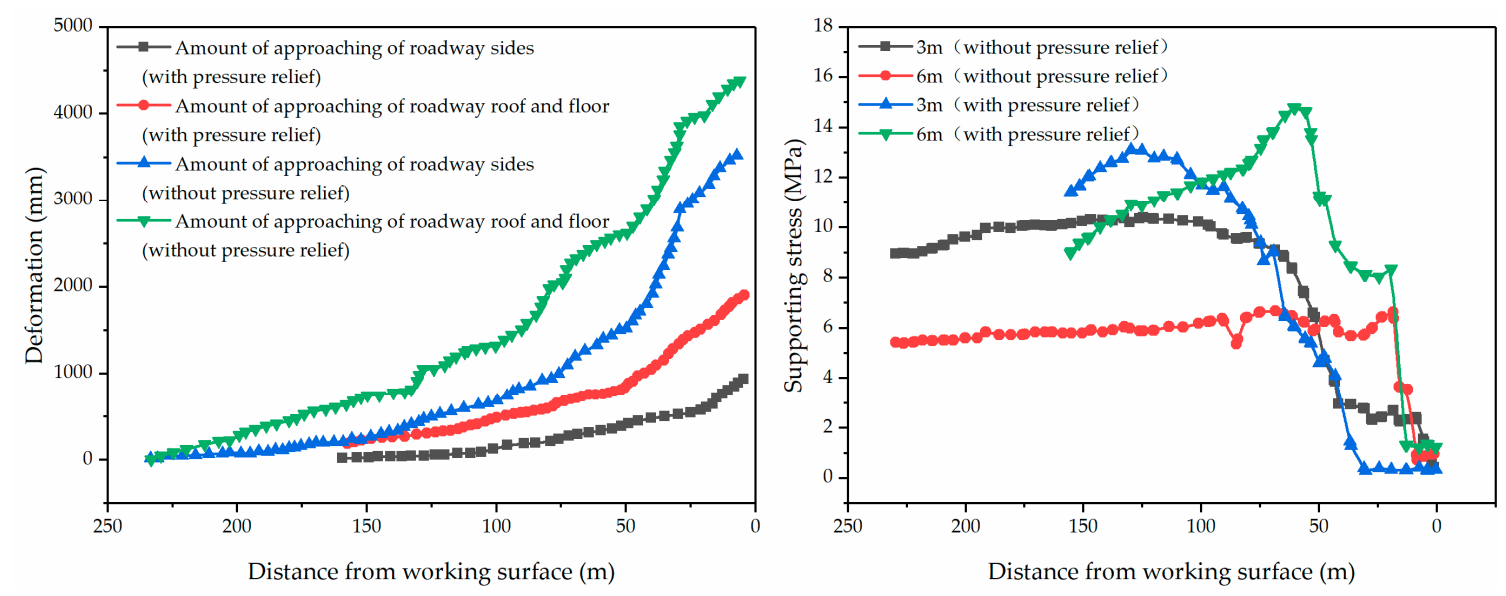

Figure 10. Field observation results.

The $15 \mathrm{~m}$ coal pillar has a smaller size (relative to a 1-km buried depth), which results in a relatively broken coal pillar and lower bearing capacity. Within $80 \mathrm{~m}$ in front of the work performed here, the supporting stress of the coal pillar gradually decreased with the advance of the caving face. The support stress of the non-pressure relief section was greater in the $6 \mathrm{~m}$ position, while the support stress of the pressure relief section was greater in the $3 \mathrm{~m}$ position, indicating that the support stress of the coal pillar was transferred to the side of the goaf due to the roof cutting and pressure relief.

Through the above analysis, we summarize the conclusions of the three research methods, as shown in Table 3. Through comparison, the effect of roof cutting on reducing roadway deformation was significant. The results of the field observation show that the deformation of the roadway was reduced by more than $50 \%$. Similarly, roof cutting can also improve the stress state of the coal pillar. The results of the physical simulation and theoretical analysis show that the stress reduction in the coal pillar was about $20 \%$. To sum up, it shows that the roof cutting and pressure relief technology is feasible in the deep-buried roadway near goafs.

Table 3. Summary of the results of different research methods.

\begin{tabular}{ccc}
\hline Contrast Item & $\begin{array}{c}\text { Reduction Percentage of } \\
\text { Roadway Deformation }\end{array}$ & $\begin{array}{c}\text { Reduction Percentage } \\
\text { of Coal Pillar Stress }\end{array}$ \\
\hline $\begin{array}{ccc}\text { Physical simulation } \\
\text { Theoretical analysis } \\
\text { Field observation }\end{array}$ & $33.4 \%$ & $21 \%$ \\
& $\geq 50 \%$ & $19.14 \%$ \\
\hline
\end{tabular}

\section{Discussion}

By analyzing the mechanism of roof cutting and pressure relief, we considered that before the working face was mined, one side of the overburdened boundary condition of the RNG was KBB of the O-X structure of the adjacent caving face, and the other side was the entity of the caving face, similar to the letter F, so it was named an " $\mathrm{F}$ "-type overburden hanging roof structure [28], as shown in Figure 11a. As shown in Figure 11b, when the caving face started to be mined, the overlying strata of the RNG formed a similar " $\mathrm{F}$ "-type overburdened hanging roof structure above the working face. In normal shallow mining operations, sectioned coal pillars are set between the working faces to isolate the overlying rock movement of the caving face and the adjacent goaf, while after performing deep mining, the coal and rock masses are located in a high-ground stress environment. After the caving face is mined, the plateau rock stress is superimposed with mining stress, and a smaller stress concentration can lead to the mass destruction of coal and rock $[29,30]$, causing the roof fracture to shift to the deep part of the coal bank. At this time, it is necessary to isolate the overburdened movement of the two working faces, i.e., to set a larger section size for the coal pillar, otherwise it will cause the 
working face and the adjacent fracture line of the overburdened goaf to overlap. The superimposed movement of KBB and KBB' of the RNG in the front section of the working face causes the instability of the double " $\mathrm{F}$ "-type hanging structure, where the ground pressure then increases, leading to the expansion of the roadway coal pillar, as shown in Figure 11c; however, setting up a larger section for the coal pillar will result in wasting resources.

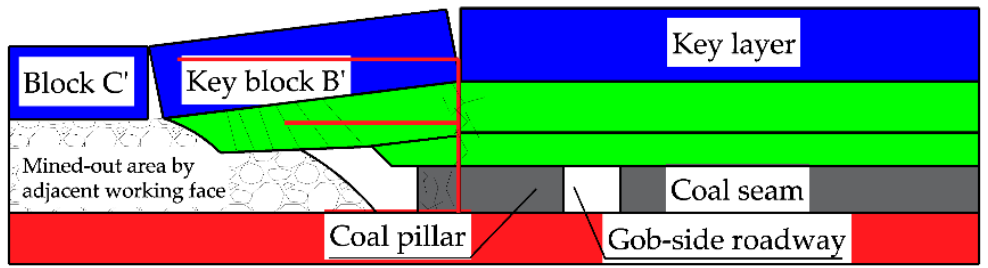

(a)

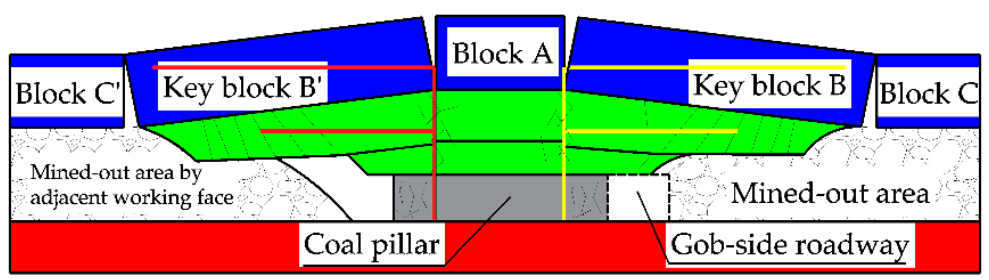

(b)

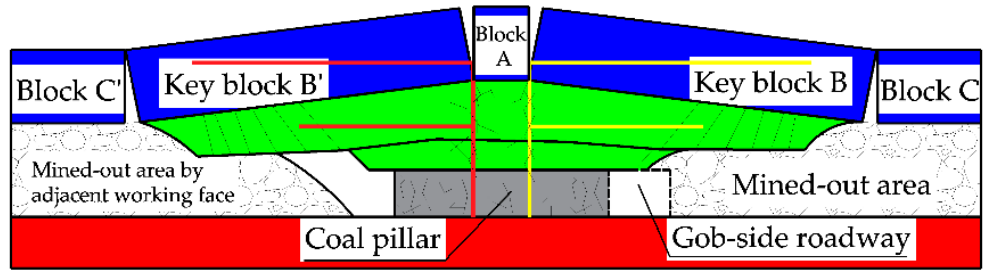

(c)

Figure 11. Layout of the overlying strata structure on the gob-side roadway.

After manual roof cutting, as shown in Figure $4 \mathrm{~b}$, part of the " $\mathrm{F}$ "-type hanging structure on the side of the goaf fell into the mined-out section along the cutting line and produced a new roof fracture. On the one hand, this reduced the length of the " $\mathrm{F}$ "-type hanging roof structure on the side of the goaf, removed the stress transfer path between the roadway roof and the overlying rock in the goaf, and weakened the superposition effect of the double " $\mathrm{F}$ " structures. On the other hand, a new fracture line caused the roof to experience a relatively large sliding deformation along the new fracture. Larger stress can be released when high superimposed supporting pressure is applied; at the same time, the cut roof can better fill the goaf, thereby changing the stress transfer between the goaf and the coal pillar. A greater distribution ratio improves the stress state of coal pillars and reduces roadway deformation.

However, the application of roof cutting and pressure relief in the deep-buried roadway near goafs also had limitations and weaknesses. For example, a roof cutting crack would reduce the effect of the bolt support, and because the RNG was a one-time use roadway, cutting the roof must be in advance of the working face to achieve the pressure relief effect, but it would also reduce the stability of the roadway roof. Roof support is a basic protection of underground mining excavations [31,32], therefore, it was significant to realize the synergy of the roof support and roof cutting to control the surrounding rock of the RNG in the deep coal mine.

The existing roof cutting pressure relief technology was usually used in retaining roadways so the pressure could be relieved by lagging the working face without considering the instability of the roadway roof caused by the pressure relief and affecting the normal use of the roadway. Roof cutting can be performed in direct roof strata. The length of roof cutting was generally short (8-15 $\mathrm{m}$ in height), 
and the direction was usually pointing to the working surface $[15,33]$. However, during the engineering verification of the 121,302 machine roadway, in order to avoid the impact of the advance in the working face pressure relief on the roadway roof and to ensure the pressure relief effect, the following measures were taken: no fracturing was carried out within the range of the anchor cable support to ensure the effectiveness of the roadway support, and a long borehole ( $47.4 \mathrm{~m}$ in height) was selected to fracture the roof of the adjacent working face goaf to cut off the $\mathrm{KBB}^{\prime}$ to ensure the effect of pressure relief.

\section{Conclusions}

(1) The overlying rock structure of an RNG will eventually become a double short-arm " $F$ "-type hanging roof structure, and the high-ground stress environment in deep mining conditions makes roof fractures shift to the deep part of coal pillars, which in turn leads to the instability of the double short-arm " $\mathrm{F}$ " structure. The superposition effect of the structure is the main cause of coal pillar expansion failure.

(2) Through the analysis of the physical similarity simulation model of surface displacement and stress data, it has been shown that manual roof cutting can reduce the vertical and horizontal approaches of a roadway and transfer the peak stress to the goaf, such that the coal pillar features a lower overall stress level.

(3) The mechanism of pressure relief by cutting the roof of an RNG in a deep coal mine suggests the following: on the one hand, manual roof cutting can reduce the stress transfer path along the roof of a roadway and the overlying rock in the mined-out area, and then weaken the superimposed effect of the double " $\mathrm{F}$ " structure; on the other hand, the roof cut induces a new fracture in the roof, and the sliding deformation along the fracture line releases greater stress. At the same time, the cut roof can better fill the goaf and change the stress distribution ratio between the goaf and the coal pillar, thereby improving the stress state of the coal pillars and reducing roadway deformation.

(4) The mechanical model of KBB was established, and the stability criterion for KBB was obtained. The results show that the stability of KBB becomes worse with the increase in mining depth. Under the existing engineering conditions, with the increase in the roof cutting length, KBB is more prone to slippage and instability, but the coal pillar force Fm decays as a quadratic function with the increase in the cutting roof length. When cutting KBB along the coal pillar, the force of the coal pillar decreases by $19.14 \%$.

(5) The field observation results show that the support stress of the coal pillar can be transferred to the side of the goaf via roof cutting, and this reduced the deformation of the roadway by more than $50 \%$ when compared with the uncut roadway section.

(6) How to ensure the safety of roof cutting and pressure relief was a key issue, so the safety factor was a very important factor. However, this paper was more inclined to analyze the mechanisms of roof cutting and pressure relief, and did not propose a safety factor, which will be studied as a key point in the follow-up research.

Author Contributions: Data curation, C.S.; formal analysis, P.L., C.S. and Y.S.; funding acquisition, P.G.; methodology, X.L. and Y.S.; software, X.L.; validation, P.G.; writing-original draft, P.L., P.G. and Y.S.; writing-review and editing, P.L. and C.S. All authors have read and agreed to the published version of the manuscript.

Funding: This article was funded by National Key R\&D Plan of China, grant number 2017YFC0603003, Applied Basic Research Project of Shanxi Province, grant number 201801D221356, and the Fund Project of Shanxi Energy Institute, grant number ZY2018001.

Conflicts of Interest: The authors declare no conflict of interest. 


\section{References}

1. Bai, J.B.; Wang, X.Y.; Hou, C.J. Research on technology of surrounding rock stability of soft rock roadway in high stress area. In Proceedings of the International Symposium on Safety Science and Technology, Jiaozuo, China, 16-19 April 2007.

2. Yang, R.S.; Li, Y.L.; Guo, D.M.; Yao, L.; Yang, T.M.; Li, T.T. Failure mechanism and control technology of water-immersed roadway in high-stress and soft rock in a deep mine. Int. J. Min. Sci. Technol. 2017, 27, 245-252. [CrossRef]

3. Chen, W.X.; He, X.Q.; Mitri, H.S.; Nie, B.S. Roadway stability analysis in a deep coal mine. In Proceedings of the International Young Scholars Symposium on Rock Mechanics, Beijing, China, 28 April-2 May 2008.

4. Xie, H.P.; Gao, M.Z.; Zhang, R.; Peng, G.Y.; Wang, W.Y.; Li, A.Q. Study on the Mechanical Properties and Mechanical Response of Coal Mining at 1000m or Deeper. Rock Mech. Rock Eng. 2019, 52, 1475-1490. [CrossRef]

5. Yuan, Y.; Wang, W.J.; Li, S.Q.; Zhu, Y.J. Failure Mechanism for Surrounding Rock of Deep Circular Roadway in Coal Mine Based on Mining-Induced Plastic Zone. Adv. Civ. Eng. 2018, 2018, 1835381. [CrossRef]

6. Sun, Y.T.; Li, G.C.; Zhang, J.F.; Qian, D.Y. Stability Control for the Rheological Roadway by a Novel High-Efficiency Jet Grouting Technique in Deep Underground Coal Mines. Sustainability 2019, 11, 6494. [CrossRef]

7. Yang, S.Q.; Chen, M.; Jing, H.W.; Chen, K.F.; Meng, B. A case study on large deformation failure mechanism of deep soft rock roadway in Xin'An coal mine, China. Eng. Geol. 2017, 217, 89-101. [CrossRef]

8. Wang, Q.; Pan, R.; Jiang, B.; Li, S.C.; He, M.C.; Sun, H.B.; Wang, L.; Qin, Q.; Yu, H.C.; Luan, Y.C. Study on failure mechanism of roadway with soft rock in deep coal mine and confined concrete support system. Eng. Fail. Anal. 2017, 81, 155-177. [CrossRef]

9. Shreedharan, S.; Kulatilake, P.H.S.W. Discontinuum-Equivalent Continuum Analysis of the Stability of Tunnels in a Deep Coal Mine Using the Distinct Element Method. Rock Mech. Rock Eng. 2016, 49, 1903-1922. [CrossRef]

10. Jiang, B.Y.; Wang, L.G.; Lu, Y.L.; Gu, S.T.; Sun, X.K. Failure Mechanism Analysis and Support Design for Deep Composite Soft Rock Roadway: A Case Study of the Yangcheng Coal Mine in China. Shock Vib. 2015, 2015, 452479. [CrossRef]

11. Xu, M.F.; Wu, S.C.; Gao, Y.T.; Ma, J.; Wu, Q.L. Analytical elastic stress solution and plastic zone estimation for a pressure relief circular tunnel using complex variable methods. Tunn. Undergr. Space Technol. 2019, 84, 381-398. [CrossRef]

12. Zhai, X.X.; Huang, G.S.; Chen, C.Y.; Li, R.B. Combined Supporting Technology with Bolt-Grouting and Floor Pressure-Relief for Deep Chamber: An Underground Coal Mine Case Study. Energies 2018, 11, 67. [CrossRef]

13. Seo, S.Y.; Ha, H. A Numerical Study on the Effect of Pressure Relief in a High-Speed Railway Tunnel. Road Rail Infrastr. 2018, 1515-1524. [CrossRef]

14. Han, C.L.; Zhang, N.; Li, B.Y.; Si, G.Y.; Zheng, X.G. Pressure relief and structure stability mechanism of hard roof for gob-side entry retaining. J. Cent. South Univ. 2015, 22, 4445-4455. [CrossRef]

15. Wang, Y.J.; Yang, J.; He, M.C.; Tian, X.C.; Liu, J.N.; Xue, H.J.; Huang, R.F. Test of a liquid directional roof-cutting technology for pressure-relief entry retaining mining. J. Geophys. Eng. 2019, 16, 620-638. [CrossRef]

16. Zhang, S.C.; Li, Y.Y.; Shen, B.T.; Sun, X.Z.; Gao, L.Q. Effective evaluation of pressure relief drilling for reducing rock bursts and its application in underground coal mines. Int. J. Rock Mech. Min. 2019, 114, 7-16. [CrossRef]

17. Song, D.Z.; Wang, E.Y.; Xu, J.K.; Liu, X.F.; Shen, R.X.; Xu, W.Q. Numerical simulation of pressure relief in hard coal seam by water jet cutting. Geomech. Eng. 2015, 8, 495-510. [CrossRef]

18. Zhang, S.G.; Chen, L.; Jia, H.Y. The Surrounding Rock of Deep Borehole Pressure Relief and Let the Pressure Bolt Coupling Analysis. Appl. Mech. Mater. 2014, 446-447, 1421-1424. [CrossRef]

19. Liu, C.K.; Ren, J.X.; Zhang, K.; Chen, S.J. Numerical studies on surrounding rock deformation controlled by pressure relief groove in deep roadway. IOP Conf. Ser. Earth Environ. Sci. 2017, 64, 012029. [CrossRef]

20. Liu, J.W.; Liu, C.Y.; Li, X.H. Determination of fracture location of double-sided directional fracturing pressure relief for hard roof of large upper goaf-side coal pillars. Energy Explor. Exploit. 2020, 38, 111-136. [CrossRef] 
21. Wang, Y.J.; He, M.C.; Yang, J.; Wang, Q.; Liu, J.N.; Tian, X.C.; Gao, Y.B. Case study on pressure-relief mining technology without advance tunneling and coal pillars in longwall mining. Tunn. Undergr. Space Technol. 2020, 97, 103236. [CrossRef]

22. Liu, H.; Dai, J.; Jiang, J.Q.; Wang, P.; Yang, J.Q. Analysis of Overburden Structure and Pressure-Relief Effect of Hard Roof Blasting and Cutting. Adv. Civ. Eng. 2019, 2019, 1354652. [CrossRef]

23. Liu, H.T.; Guo, L.F.; Cao, G.M.; Zhao, X.D.; Wang, P.F.; Huo, T.H.; Yang, G.; Hao, C.; Wang, Q. Comprehensive Study of Strata Movement Behavior in Mining a Longwall Top Coal Caving Panel of a Composite Coal Seam with Partings. Appl. Sci. 2020, 10, 5311. [CrossRef]

24. Fang, F.; Shu, C.; Wang, H.T. Physical simulation of upper protective coal layer mining with different coal seam inclinations. Energy Sci. Eng. 2020, 8, 3103-3116. [CrossRef]

25. Xu, Z.H.; Li, Q.S.; Li, X.B. Overburden Migration and Failure Characteristics in Mining Shallow Buried Coal Seam with Thick Loose Layer. Adv. Mater. Sci. Eng. 2020, 2020, 9024751. [CrossRef]

26. Zhang, D.S.; Miao, X.X.; Ma, L.Q.; Feng, G.M. Technique of gob-side entry retaining with entry-in packing in fully-mechanized coalface with top-coal caving. In Proceedings of the 5th International Symposium on Mining Science and Technology, Xuzhou, China, 20-22 October 2004.

27. Bai, J.B.; Shen, W.L.; Guo, G.L.; Wang, X.Y.; Yu, Y. Roof Deformation, Failure Characteristics, and Preventive Techniques of Gob-Side Entry Driving Heading Adjacent to the Advancing Working Face. Rock Mech. Rock Eng. 2015, 48, 2447-2458. [CrossRef]

28. Linming, D.; Hu, H. Study of OX-FT spatial structure evolution of overlying strata in coal mines. Chin. J. Rock Mech. Eng. 2012, 31, 453-460.

29. Xie, J.L.; Xu, J.L.; Wang, F. Mining-induced stress distribution of the working face in a kilometer-deep coal mine-a case study in Tangshan coal mine-a case study in Tangshan coal mine. J. Geophys. Eng. 2018, 15, 2060-2070. [CrossRef]

30. Chen, Y.L.; Lu, A.H.; Mao, X.B.; Li, M.; Zhang, L.Y. Nonlinear Dynamics Mechanism of Rock Burst Induced by the Instability of the Layer-Crack Plate Structure in the Coal Wall in Deep Coal Mining. Shock Vib. 2017, 2017, 4051967. [CrossRef]

31. Szurgacz, D.; Brodny, J. Tests of Geometry of the Powered Roof Support Section. Energies 2019, $12,3945$. [CrossRef]

32. Szurgacz, D.; Brodny, J. Adapting the Powered Roof Support to Diverse Mining and Geological Conditions. Energies 2020, 13, 405. [CrossRef]

33. He, M.C.; Gao, Y.B.; Yang, J.; Gong, W.L. An Innovative Approach for Gob-Side Entry Retaining in Thick Coal Seam Longwall Mining. Energies 2017, 10, 1785. [CrossRef]

Publisher's Note: MDPI stays neutral with regard to jurisdictional claims in published maps and institutional affiliations.

(C) 2020 by the authors. Licensee MDPI, Basel, Switzerland. This article is an open access article distributed under the terms and conditions of the Creative Commons Attribution (CC BY) license (http://creativecommons.org/licenses/by/4.0/). 